\title{
Assessment of Morphological, Physiological and Yield Response of Varagu with Legume Intercropping Planting System
}

\author{
K. Ananthi ${ }^{*}$ and P. Parasuraman ${ }^{2}$ \\ ${ }^{1}$ Department of Crop Physiology, ${ }^{2}$ Department of Agronomy, \\ Centre of Excellence in Millets, Athiyandal, India \\ *Corresponding author
}

\section{A B S T R A C T}

\begin{tabular}{l}
\hline Ke y w o r d s \\
Intercropping, Leaf \\
area, Relative \\
water content, \\
Forage, Yield, \\
Productivity \\
\hline Article Info \\
\hline $\begin{array}{l}\text { Accepted: } \\
\text { 26 April } 2020 \\
\text { Available Online: } \\
\text { 10 May } 2020\end{array}$ \\
\hline
\end{tabular}

\begin{abstract}
Many intercropping system have proved to be better than sole crops in terms of yield because intercropping makes better use of one or more agricultural resources both in time and in space. Planting uniformly or nearly uniformly over the land to reduce early interplant competition and increase the rate of solar radiation interception. The principal advantage of intercropping system is the more efficient utilization of soil, water, nutrient and increased productivity compared with each sole crop under rainfed and irrigated ecosystem. Selection of the right small millet intercropping combination is more important in dry land cropping system due to the reason that competition of plant could be minimized not only by spatial arrangement, but also by combining those crops which have best able to exploit soil nutrients. A field study was scheduled to estimate the impact of intercropping varagu with greengram and blackgram cropping system under rain-fed and irrigated situation on photosynthetic efficiency, forage and grain yield at Centre of Excellence in Millets, Athiyandal, Tiruvannamalai. It was done in Kharif, 2018 and 2019. Randomized block design was used to conduct this experiment. It has three replications. The aim of this study was to evaluate and compare varagu with greengram and blackgram inter cropping effects on irrigated and rainfed ecosystem on leaf area, relative water content and yield as well as reveal which intercrops better adopts to rainfed cropping systems using these parameters to improve water use efficiency in the production.
\end{abstract}

\section{Introduction}

Water shortage is threatening crop production and agricultural sustainability (Piao et al., 2010). An added pressure is the severe competition for water resources between agricultural sector and the fast-developing urbanization (Kendy et al., 2007; Poumanyvong et al., 2012). Chai et al., (2014) describes various means have been used to save water in agriculture, including the adoption of regulated irrigation in crop production and the use of innovative water saving practices.

Yin et al., (2015) reported that one of the most effective approaches to improve water use efficiency in the production of field crops. Intercropping has been reported to enhance soil water conservation and reduce run-of 
(Sharma et al., 2017), increase the use of available soil water (Yang et al., 2011 and $\mathrm{Hu}$ et al., 2017) and improve crop yield for the entire systems and the yield per unit of water supplied (Borghi et al., 2013; Qin et al., 2013), as well as the yield of crops grown the following year in the rotation. Many intercropping system have proved to be better than sole crops in terms of yield (Zhang et al., 2007) because intercropping makes better use of one or more agricultural resources both in time and in space. Small millets - a group of six crops / minor coarse cereals, namely finger millet (Eleusine coracana), little millet (Panicum miliare), kodo millet (Paspalum scrobiculatum), foxtail millet (Setaria italica), barnyard millet (Echniochola frumentacea) and proso millet (Panicum miliaceum), representing the area grown in that order. These crops have traditionally been the indispensable component of dry farming system. Millets possess several morphophysiological, molecular and biochemical characteristics which confer better tolerance to environmental stresses than major cereals. Primarily, the short lifecycle of millets assists in escaping from stress as they require 12-14 weeks to complete their life-cycle (seed to seed) whereas rice and wheat requires a maximum of 20-24 weeks.

However, the prevalence of stress conditions and their consequences are circumvented by several traits such as short stature, small leaf area, thickened cell walls, and the capability to form dense root system. Also, the C4 photosynthetic trait is highly advantageous to millets. If we intercrop millets with any legume crop like varagu with blackgram and varagu with greengram then its uality can be made better due to enhanced protein percentage. Varagu cultivated for forage and grain purpose. It is highly tolerant of heat and water shortage. It is good in producing a lot of grain and shortage; that's why it is most liked by farmers.
If we intercrop millet with any legume crop then its quality can be made better. Legumes to be very good nitrogen fixers; that's why legumes are considered to be good and if they are grown with non-leguminous crops then it gives good quality grain and forage yield. These are also believed to reduce the cost of nitrogen application as they are already fixing nitrogen from atmosphere (Anil et al., 1998).

It's intercropping with non-leguminous crops not only a reason of increase in production of forage but quality is also enhanced due to high level of protein level then cereals. Cereals are also grown in tropical areas with legumes (Nielsen and Jensen, 2001). This practice is also done in rain fed areas (Agegnehu and sinebo, 2006). We get higher yields in intercropping system than sole system (Lithourgidis et al., 2006).

Growing of legumes with cereals also helps in improving the overall condition of soil by nitrogen fixation (Eaglesham et al., 1981). Fixed nitrogen by the legumes then transferred to cereals growing with legumes that are also much essential to crops (Shen and Chu, 2004). Sowing of mixed seed increases the yield, and quality if done with legumes (Ahmed et al., 2007). Main purpose of this practice is to get higher yield by using all sources that are available at that time which may be not used by a single crop.

\section{Materials and Methods}

A field study was scheduled to estimate the impact of intercropping varagu with greengram and blackgram cropping system under rain-fed and irrigated situation at Centre of Excellence in Millets, Athiyandal, Tiruvannamalai. It was done in Kharif, 2018 and 2019. Randomized block design was used to conduct this experiment. It has three replications. The experiment is comprised of 8 treatments are as follows: 


$$
\begin{aligned}
& \mathrm{T}_{1}-\text { Sole Varagu }(45 \times 10 \mathrm{~cm}) \\
& \mathrm{T}_{2}-\text { Paired row Varagu }(60: 30 \times 10 \mathrm{~cm}) \\
& \mathrm{T}_{3}-\text { Paired row Varagu + Groundnut }(1: 1) \\
& \mathrm{T}_{4}-\text { Paired row Varagu + Black gram }(1: 1) \\
& \mathrm{T}_{5}-\text { Paired row Varagu + Green gram }(1: 1) \\
& \mathrm{T}_{6}-\text { Sole Varagu + Groundnut }(1: 1) \\
& \mathrm{T}_{7}-\text { Sole Varagu + Black gram }(1: 1) \\
& \mathrm{T}_{8}-\text { Sole Varagu + Green gram }(1: 1)
\end{aligned}
$$

The seed rate for varagu is $10-12.5 \mathrm{~kg} / \mathrm{ha}$, greengram and blackgram for $10 \mathrm{~kg} / \mathrm{ha}$ is used. Varagu variety $\mathrm{CO} 3$, Blackgram TNAU (Bg) VBN 7, Greengram VBN (Gg) 2 and Groundnut TMV (Gn) 13 were sown in lines. All agronomic practices are considered as normal for all the treatments except those which were under study.

\section{Results and Discussion}

The data presented in Table 1, 2, 3 and 4 proved that intercropping of varagu with blackgram, greengram and groundnut significantly affected the morphological, physiological and yield parameters such as plant height, leaf area, relative water content, grain yield and straw yield.

\section{Plant height (cm) of varagu with intercropping on rainfed and irrigated condition}

Plants were harvested at different growth stages for growth analysis at vegetative, panicle initiation, grain filling and harvesting stages. The treatment $\mathrm{T}_{7}-$ Sole Varagu + Black gram (1:1) intercropping performed well under rain-fed condition with less reduction in plant height $(78.3 \mathrm{~cm})$ of varagu. In irrigated condition, treatment $\mathrm{T}_{1}-$ Sole Varagu $(45 \times 10 \mathrm{~cm})$ gave maximum height (71.0) $\mathrm{cm}$, due to no competition in this treatment. It is followed by treatment $\mathrm{T}_{7}$ Sole Varagu + Black gram (1:1) intercropping which shows plant height $(67.3 \mathrm{~cm})$. among the intercropping treatment $\mathrm{T}_{7}-$ Sole Varagu
+ Black gram (1:1) gave maximum height $(78.3 \mathrm{~cm})$ when compare to other treatments. In intercropping, it is revealed that due to intercropping of varagu with legumes, treatment $\mathrm{T}_{7}-$ Sole Varagu + Black gram (1:1), Blackgram gave maximum height (44.7 $\mathrm{cm})$ under under rainfed condition. Ahmad et al., (2007) also said that there was clear variation in the height of sorghum plants when it was intercropped with other crops.

\section{Leaf area and relative water contend of varagu with intercropping on rainfed and irrigated condition}

Leaf surfaces are the primary photosynthetic organs of the plant, it is sometimes desirable to express growth on a leaf area basis. Leaf area development in annual crops, radiation interception by leaves increases. Since flowering terminates leaf area development, cultural objectives are to maximize photosynthesis by the crop intercepting all or nearly all of the solar radiation. This is an efficient pattern for grain crops, in which the majority of seed weight comes from photosynthesis after flowering. Early growth of individual plants, with little plant-to-plant competition, is described by the relative growth rate, which is based on the rate of dry matter increase in relation to the dry matter weight of the whole plant. The varagu plants treatment $\mathrm{T}_{7}$ (Sole Varagu with Black gram (1:1)) gave highest leaf area $\left(684.2 \mathrm{~cm}^{2}\right.$ plant $^{-1}$ ) under irrigated condition, followed by $\mathrm{T}_{8}$ [Sole Varagu with Black gram (1:1)] $\left(635.2 \mathrm{~cm}^{2}\right.$ plant $\left.^{-1}\right)$. The plants of treatment $\mathrm{T}_{4}$ (Paired row Varagu with Black gram (1:1)) gave maximum relative water content $(89 \%)$ under rain-fed condition followed by $\mathrm{T}_{7}$ [Sole Varagu with Black gram (1:1)] (87\%). This results shows, $\mathrm{T}_{7}$ treatment [Sole Varagu with Black gram (1:1)] plant to plant competition is very low; which results in efficient use of solar radiation. 
Table.1 Performance of varagu based intercropping system on Plant height $(\mathrm{cm})$, Leaf area $\left(\mathrm{cm}^{2}\right.$ plant $\left.^{-1}\right)$, Relative Water Content $(\%)$, Grain yield $(\mathrm{kg} / \mathrm{ha})$ and Straw yield (kg / ha) on rain-fed varagu

\begin{tabular}{|c|c|c|c|c|c|}
\hline Treatments & $\begin{array}{l}\text { Plant height } \\
(\mathrm{cm})\end{array}$ & $\begin{array}{c}\text { Leaf Area } \\
\left(\mathrm{cm}^{2} \text { plant }^{-1}\right)\end{array}$ & $\begin{array}{c}\text { Relative Water } \\
\text { Content }(\%)\end{array}$ & $\begin{array}{l}\text { Grain yield } \\
\text { (kg/ha) }\end{array}$ & $\begin{array}{l}\text { Straw yield } \\
(\mathrm{kg} / \mathrm{ha})\end{array}$ \\
\hline $\begin{array}{l}T_{1}-\text { Sole Varagu }(45 \times 10 \\
\mathrm{cm})\end{array}$ & 69.3 & 519.1 & 85 & 1525 & 4605 \\
\hline $\begin{array}{l}\mathrm{T}_{2}-\text { Paired row Varagu } \\
(60: 30 \times 10 \mathrm{~cm})\end{array}$ & 66.3 & 435.0 & 83 & 1502 & 4458 \\
\hline $\begin{array}{l}T_{3}-\text { Paired row Varagu + } \\
\text { Groundnut (1:1) }\end{array}$ & 65.7 & 401.1 & 84 & 1530 & 4458 \\
\hline $\begin{array}{l}T_{4}-\text { Paired row Varagu + } \\
\text { Black gram(1:1) }\end{array}$ & 73.0 & 500.3 & 89 & 1584 & 4739 \\
\hline $\begin{array}{l}T_{5}-\text { Paired row Varagu + } \\
\text { Green gram (1:1) }\end{array}$ & 75.3 & 478.3 & 85 & 1561 & 4678 \\
\hline $\begin{array}{l}T_{6}-\text { Sole Varagu + } \\
\text { Groundnut }(1: 1)\end{array}$ & 68.3 & 436.5 & 83 & 1360 & 4563 \\
\hline $\begin{array}{l}T_{7}-\text { Sole Varagu + Black } \\
\text { gram (1:1) }\end{array}$ & 78.3 & 528.8 & 87 & 1613 & 4938 \\
\hline $\begin{array}{l}T_{8}-\text { Sole Varagu + Green } \\
\text { gram (1:1) }\end{array}$ & 71.3 & 511.1 & 85 & 1580 & 4866 \\
\hline SEd & 4.4 & 5.6 & 1.3 & 28 & 185 \\
\hline $\mathrm{CD}(\mathrm{P}=\mathbf{0 . 0 5})$ & 9.6 & 12.2 & 2.7 & 60 & 400 \\
\hline
\end{tabular}

Table.2 Performance of varagu based intercropping system on Plant height $(\mathrm{cm})$, Leaf area $\left(\mathrm{cm}^{2}\right.$ plant $\left.^{-1}\right)$, Relative Water Content (\%), Grain yield (kg / ha) and Straw yield ( $\mathrm{kg} / \mathrm{ha})$ on irrigated varagu

\begin{tabular}{|c|c|c|c|c|c|}
\hline Treatments & $\begin{array}{l}\text { Plant height } \\
\quad(\mathrm{cm})\end{array}$ & $\begin{array}{l}\text { Leaf Area } \\
\left(\mathrm{cm}^{2} \text { plant }^{-1}\right)\end{array}$ & $\begin{array}{c}\text { Relative Water } \\
\text { Content }(\%)\end{array}$ & $\begin{array}{l}\text { Grain yield } \\
\text { (kg/ha) }\end{array}$ & $\begin{array}{l}\text { Straw yield } \\
(\mathrm{kg} / \mathrm{ha})\end{array}$ \\
\hline $\begin{array}{l}T_{1}-\text { Sole Varagu }(45 \times 10 \\
\mathrm{cm})\end{array}$ & 71.0 & 484.1 & 86 & 1856 & 4615 \\
\hline $\begin{array}{l}T_{2}-\text { Paired row Varagu } \\
(60: 30 \times 10 \mathrm{~cm})\end{array}$ & 66.7 & 465.4 & 88 & 1822 & 4602 \\
\hline $\begin{array}{l}T_{3}-\text { Paired row Varagu }+ \\
\text { Groundnut (1:1) }\end{array}$ & 62.3 & 593.0 & 81 & 1421 & 3523 \\
\hline $\begin{array}{l}T_{4}-\text { Paired row Varagu }+ \\
\text { Black gram (1:1) }\end{array}$ & 66.0 & 603.8 & 83 & 1551 & 4143 \\
\hline $\begin{array}{l}T_{5}-\text { Paired row Varagu }+ \\
\text { Green gram(1:1) }\end{array}$ & 59.3 & 568.6 & 85 & 1475 & 3795 \\
\hline $\begin{array}{l}T_{6}-\text { Sole Varagu }+ \\
\text { Groundnut }(1: 1)\end{array}$ & 62.0 & 621.4 & 85 & 1672 & 3731 \\
\hline $\begin{array}{l}\mathbf{T}_{7}-\text { Sole Varagu + Black } \\
\operatorname{gram}(1: 1)\end{array}$ & 67.3 & 684.2 & 86 & 1880 & 4347 \\
\hline $\begin{array}{l}\mathbf{T}_{8}-\text { Sole Varagu + Green } \\
\operatorname{gram}(1: 1)\end{array}$ & 64.3 & 635.2 & 86 & 1748 & 4258 \\
\hline SEd & 1.5 & 3.88 & 0.84 & 11 & 23 \\
\hline $\mathrm{CD}(\mathrm{P}=0.05)$ & 3.3 & 8.39 & 1.83 & 24 & 51 \\
\hline
\end{tabular}


Table.3 Performance of varagu based intercropping system on Plant height $(\mathrm{cm})$, Leaf area $\left(\mathrm{cm}^{2}\right.$ plant $\left.{ }^{-1}\right)$, Relative Water Content $(\%)$, Grain yield $(\mathrm{kg} / \mathrm{ha})$ and

Straw yield (kg / ha) on intercropping at rain-fed condition

\begin{tabular}{|l|c|c|c|c|c|}
\hline Treatments & $\begin{array}{c}\text { Plant height } \\
(\mathbf{c m})\end{array}$ & $\begin{array}{c}\text { Leaf Area } \\
\left(\mathbf{c m}^{\mathbf{2}} \mathbf{p l a n t}^{\mathbf{1}} \mathbf{)}\right.\end{array}$ & $\begin{array}{c}\text { Relative Water } \\
\text { Content } \mathbf{( \% )}\end{array}$ & $\begin{array}{c}\text { Grain yield } \\
(\mathbf{k g} / \mathbf{h a})\end{array}$ & $\begin{array}{c}\text { Straw yield } \\
(\mathbf{k g} / \mathbf{h a})\end{array}$ \\
\hline $\begin{array}{l}\mathbf{T}_{\mathbf{3}} \text { - Paired row Varagu + } \\
\text { Groundnut (1:1) }\end{array}$ & 58.0 & 280.9 & 83 & 837 & 1028 \\
\hline $\begin{array}{l}\mathbf{T}_{\mathbf{4}} \text { - Paired row Varagu + } \\
\text { Black gram (1:1) }\end{array}$ & 36.3 & 360.4 & 87 & 668 & 1126 \\
\hline $\begin{array}{l}\mathbf{T}_{\mathbf{5}} \text { - Paired row Varagu + } \\
\text { Green gram(1:1) }\end{array}$ & 65.3 & 828.1 & 85 & 634 & 1601 \\
\hline $\begin{array}{l}\mathbf{T}_{\mathbf{6}} \text { - Sole Varagu + } \\
\text { Groundnut (1:1) }\end{array}$ & 62.3 & 279.3 & 82 & 1064 & 1341 \\
\hline $\begin{array}{l}\mathbf{T}_{\mathbf{7}}-\text { Sole Varagu + Black } \\
\text { gram (1:1) }\end{array}$ & 44.7 & 413.4 & 85 & 1210 & 2084 \\
\hline $\begin{array}{l}\mathbf{T}_{\mathbf{8}} \text { - Sole Varagu + Green } \\
\text { gram (1:1) }\end{array}$ & 67.3 & 859.5 & 83 & 1125 & 2678 \\
\hline SEd & 4.6 & 6.1 & 0.51 & 18 & 42 \\
\hline CD (P=0.05) & 10.4 & 13.8 & 1.15 & 41 & 95 \\
\hline
\end{tabular}

Table.4 Performance of varagu based intercropping system on Plant height $(\mathrm{cm})$, Leaf area $\left(\mathrm{cm}^{2}\right.$ plant $\left.{ }^{-1}\right)$, Relative Water Content $(\%)$, Grain yield $(\mathrm{kg} / \mathrm{ha})$ and Straw yield ( $\mathrm{kg} / \mathrm{ha})$ on intercropping at irrigated condition

\begin{tabular}{|l|c|c|c|c|c|}
\hline Treatments & $\begin{array}{c}\text { Plant height } \\
(\mathbf{c m})\end{array}$ & $\begin{array}{c}\text { Leaf Area } \\
\left(\mathbf{c m}^{\mathbf{2}} \mathbf{p l a n t}^{\mathbf{1}} \mathbf{)}\right.\end{array}$ & $\begin{array}{c}\text { Relative Water } \\
\text { Content } \mathbf{( \% )}\end{array}$ & $\begin{array}{c}\text { Grain yield } \\
(\mathbf{k g} / \mathbf{h a})\end{array}$ & $\begin{array}{c}\text { Straw yield } \\
(\mathbf{k g} / \mathbf{h a})\end{array}$ \\
\hline $\begin{array}{l}\mathbf{T}_{\mathbf{3}} \text { - Paired row Varagu + } \\
\text { Groundnut (1:1) }\end{array}$ & 53.7 & 209.3 & 81 & 898 & 1767 \\
\hline $\begin{array}{l}\mathbf{T}_{\mathbf{4}} \text { - Paired row Varagu + } \\
\text { Black gram (1:1) }\end{array}$ & 40.3 & 525.4 & 83 & 885 & 1892 \\
\hline $\begin{array}{l}\mathbf{T}_{\mathbf{5}} \text { - Paired row Varagu + } \\
\text { Green gram (1:1) }\end{array}$ & 49.0 & 867.5 & 82 & 840 & 2661 \\
\hline $\begin{array}{l}\mathbf{T}_{\mathbf{6}} \text { - Sole Varagu + } \\
\text { Groundnut (1:1) }\end{array}$ & 61.0 & 280.6 & 83 & 1131 & 2330 \\
\hline $\begin{array}{l}\mathbf{T}_{\mathbf{7}} \text { - Sole Varagu + Black } \\
\text { gram (1:1) }\end{array}$ & 42.7 & 556.8 & 84 & 1215 & 2375 \\
\hline $\begin{array}{l}\mathbf{T}_{\mathbf{8}} \text { - Sole Varagu + Green } \\
\text { gram (1:1) }\end{array}$ & 51.7 & 886.5 & 80 & 1159 & 3331 \\
\hline SEd & 0.6 & 22.8 & 0.86 & 15 & 193 \\
\hline CD (P=0.05) & 1.4 & 51.4 & 1.93 & 34 & 435 \\
\hline
\end{tabular}

Grain yield (kg/ha) and straw yield (kg/ha) of varagu with intercropping on rainfed and irrigated condition

Donald (1963) suggested that the grater seed weight and number of seeds per inflorescence at intermediate densities are due to the timing of interplant (between plants) and intra plant (within a plant) competition. At the widest spacing (lowest plant density), both types of competition are absent during early stages of growth. The treatment $\mathrm{T}_{7}$ [Sole Varagu with Black gram (1:1)] under irrigated $(1880 \mathrm{~kg} / \mathrm{ha}$ and $1613 \mathrm{~kg} / \mathrm{ha})$ and rain-fed (4347 kg/ha and $4938 \mathrm{~kg} / \mathrm{ha}$ ) condition shows the highest value of varagu grain yield and straw yield 
than the other treatment. Chellaiah and Earnet (1994) indicated that when sorghum was intercropped with cowpea then their intercrop combinations produced higher yield of fresh and dry matter as compared to their sole combinations. These variations are because of variation in fertility level in soil, change in species selected and prevailing environmental conditions. The treatment $\mathrm{T}_{7}$ (Sole Varagu with Black gram (1:1)) intercropping produced maximum grain yield and straw yield (1215 kg/ha and $2375 \mathrm{~kg} / \mathrm{ha})$ under irrigated and $(1210 \mathrm{~kg} / \mathrm{ha}$ and $2084 \mathrm{~kg} / \mathrm{ha})$ under rainfed condition. Marchiol et al., (1992) found that there was increase in the amount of protein contents in intercrop treatments as compared with sole maize.

Climate change and water scarcity may increase number of extreme weather events in the future agricultural crop production. Innovative and effective approaches are needed to alleviate the challenge. In the present study, we determined the sole varagu with blackgram intercropping 1:1 ratio, sharing soil water and nutrients between intercrops during the crop growth period. Using sole varagu with blackgram intercropping 1:1 ratio improves crop productivity through soil water sharing and compensation in water scarcity areas.

\section{References}

Agegnehu, G., Ghizam, A. and Sinebo, W. (2006) Yield performance and land use efficiency of barley and faba bean mixed cropping in Ethopian High Lands. European Journal of Agronomy, 25, 202-207. https://doi.org/10.1016/j.eja.2006.05.0 02

Ahmad, A., Ahmad, R., Mahmood, N. and Tanveer, A. (2007) Performance of Forage Sorghum Intercropped with
Forage Legumes under Different Planting Patterns. Pakistan Journal of Botany, 39, 431-439.

Anil, L., Park, J., Phipps, R.H. and Miller, F.A. (1998) Temperate Intercropping of Cereals for Forage: A Review of the Potential for Growth and Utilization with Particular Reference to the UK. Grass and Forage Science, 53 , 301-317. https://doi.org/10.1046/j.13652494.1998.00144.X

Borghi, E. et al., 2013. Sorghum grain yield, forage biomass production and revenue as afected by intercropping time. Eur. J. Agron. 51, 130-139.

Borghi, E., Crusciol, C. A. C., Mateus, G. P., Nascente, A. S. and Martins, P. O. 2013. Intercropping time of corn and palisadegrass or guineagrass affecting grain yield and forage production. Crop Sci. 53, 629-636.

Chai, Q. et al., Water-saving innovations in Chinese agriculture. Adv. Agron. 126, 149-201 (2014).

Chellaiah, N. and Earnest, J. (1994) Fodder Production of Cereal Legume Mixture. Livestock Advisor, 19, 15-18.

Donald, C.M.1963. Adv. Agron. 15: 1-118. Eaglesham, A.R.J., Ayanaba, A., Rao, V.R. and Eskew, D.C. (1981) Improving the Nitrogen Nutrition of Maize by Intercropping with Cowpea. Soil Biology and Biochemistry, 13, 231234.

Hauggard-Nielsen, H. and Jensen, E.S. (2001) Evaluating Pea and Barley Cultivars for Complimentary in Intercropping Different Levels Soil N Availability. Field Crops Research, 72, 185-196. https://doi.org/10.1016/S03784290(01)00176-9.

$\mathrm{Hu}, \mathrm{F}$. et al., 2017. Integration of wheatmaize intercropping with conservation practices reduces $\mathrm{CO}_{2}$ emissions and enhances water use in dry areas. Soil 
and Tillage Res. 169, 44-53.

Kendy, E. et al., Can urbanization solve intersector water conficts? Insight from a case study in Hebei Province, North China Plain. Water Policy 9, 75-93 (2007).

Lithourgidis, A.S., Vasilakoglou, I.B., Dhima, K.V., Dordas, C.A. and Yiakoulaki, M.D. (2006) Forage Yield and Quality of Common Vetch Mixtures with Oat and Triticale in Two Seeding Ratios. Field Crops Research, 99, 106-113.

Marchiol, L., Miceli, F., Eiosa, M. and Zerbi, G. (1992) Intercropping of Soybean and Maize for Silage in Nothern Italy. Effect of Nitrogen Level and Plant Density on Growth, Yield and Protein Contents. European Journal of Agronomy, 1, 207-211. https://doi.org/10.1016/S11610301(14)80071-3

Piao, S. L. et al., 2010. Te impacts of climate change on water resources and agriculture in China. Nature 467, 43-51. 7.

Poumanyvong, P., Kaneko, S. and Dhakal, S.2012. Impacts of urbanization on national transport and road energy use: Evidence from low, middle and high income countries. Energy Policy
46, 268-277.

Qin, A. Z., Huang, G. B., Chai, Q., Yu, A. Z. and Huang, P. 2013.Grain yield and soil respiratory response to intercropping systems on arid land. Field Crops Res. 144, 1-10.

Sharma, N. K. et al., 2017. Increasing farmer's income and reducing soil erosion using intercropping in rainfed maize-wheat rotation of Himalaya, India. Agriculture, Ecosystems and Environment 247, 43-53.

Shen, Q.R. and Chu, G.X. (2004) BiDirectional Nitrogen Transfer in an Intercropping System of Peanut with Rice Cultivated in aerobic Soil. Biology and Fertility of Soils, 40, 8187. https://doi.org/10.1007/s00374004-0737-3

Yang, C., Huang, G., Chai, Q. and Luo, Z.2011. Water use and yield of wheat/maize intercropping under alternate irrigation in the oasis field of northwest China. Field Crops Res. 124,426-432.

Yin, W. et al., 2015. Wheat and maize relayplanting with straw covering increases water use efficiency up to $46 \%$. Agron. Sustain. Dev. 35, 815-825.

\section{How to cite this article:}

Ananthi, K. and Parasuraman, P. 2020. Assessment of Morphological, Physiological and Yield Response of Varagu with Legume Intercropping Planting System. Int.J.Curr.Microbiol.App.Sci. 9(05): 3295-3301. doi: https://doi.org/10.20546/ijcmas.2020.905.391 